\title{
30. ORIGINS AND PALEOCEANOGRAPHIC SIGNIFICANCE OF LAMINATED DIATOM OOZE FROM THE EASTERN EQUATORIAL PACIFIC OCEAN ${ }^{1}$
}

\author{
Alan E.S. Kemp, ${ }^{2}$ Jack G. Baldauf, ${ }^{3}$ and Richard B. Pearce ${ }^{2}$
}

\begin{abstract}
Laminated diatom ooze (LDO) has been recovered from several Ocean Drilling Program (ODP) Leg 138 sites and, now, is also recognized from several Deep Sea Drilling Project (DSDP) Leg 85 sites. These remarkable sediments are the result of massive and episodic flux of mats of the diatom Thalassiothrix longissima. By analogy with the Rhizosolenia diatom mat-forming events monitored by the Joint Global Ocean Flux Study (JGOFS) in the equatorial Pacific Ocean during cooling conditions in Fall 1992 (Barber, 1992; Barber et al., in press), these episodes of massive flux of $T$. longissima mats may represent the "fall out" from major frontal systems generated during La Niña (anti-El Niño) events. Laminations were preserved in the mat deposits because of the rapid mat deposition and high strength of the diatom mat meshwork, which subjugated benthic activity. This new mechanism of preservation of lamination in marine sediments has wide implications for other laminated sequences. The sustained periods of mat deposition documented in Neogene sediments of the eastern equatorial Pacific Ocean are part of the major cycles in the relative abundance of carbonate and silica in the region and, possibly, in the case of some intervals, also in the Atlantic Ocean.
\end{abstract}

\section{INTRODUCTION}

The eastern equatorial Pacific Ocean is a region deemed responsible for up to half of global "new" production and is a continuing focus for studies of modern oceanic and climatic processes, including most recently, the U.S. JGOFS program (Wyrtki, 1981; Chavez and Barber, 1987; Chavez et al., 1990; Barber, 1992; Barber et al., in press). Furthermore, changes in its sedimentary record have often recorded important paleoceanographic events and heralded major reorganizations in ocean and climate history (van Andel et al., 1975; Mayer, Theyer, Thomas, et al., 1985; Mayer, Pisias, Janecek, et al., 1992). ODP Leg 138 furnished a high-resolution record of the last 10- to 15-m.y. depositional history of the eastern equatorial Pacific between $90^{\circ}$ and $110^{\circ} \mathrm{W}$ (Fig. 1). The intervals of greatest diatom abundance are recorded by near-monospecific assemblages of the pennate diatom Thalassiothrix longissima that occur in LDOs, which have been interpreted as diatom mat deposits (Kemp and Baldauf, 1993). The detailed sedimentology, micropaleontology, and microfacies of the LDO are discussed elsewhere (Pearce et al., this volume). The purpose of this study is to review evidence for the origins and paleoceanographic significance of these remarkable sediments. The time scale used below is that of Berggren et al. (1985), as rendered in the Leg 138 "Explanatory Notes" chapter of Mayer, Pisias, Janecek, et al. (1992).

The discovery of these laminated diatom mat deposits comes against an increasing awareness of both (1) the importance of relatively rare events in contributing a major proportion of flux to the seabed (e.g., Smith et al., 1992) and (2) the significance of buoyant diatom mats and individual large diatoms for nutrient-cycling within the ocean surface layer (Villareal et al., 1993) and as agents of rapid flux to the seafloor (Sancetta et al., 1991).

\section{SUMMARY OF GEOGRAPHIC AND TEMPORAL DISTRIBUTION OF LDO}

LDO was recovered from Leg 138 Sites $844,847,849,850$, and 851. Investigation of DSDP Leg 85 cores established the presence of

\footnotetext{
${ }^{1}$ Pisias, N.G., Mayer, L.A., Janecek, T.R., Palmer-Julson, A., and van Andel, T.H. (Eds.), 1995. Proc. ODP, Sci. Results, 138: College Station, TX (Ocean Drilling Program).

${ }^{2}$ Department of Oceanography, University of Southampton, Southampton SO9 5NH, United Kingdom.

${ }^{3}$ Department of Oceanography and Ocean Drilling Program, Texas A\&M University, College Station, TX 77845, U.S.A.
}

laminated diatom ooze in Sites 572,573 , and 574 (Fig. 2). Thus, the latitudinal extent of the $\mathrm{LDO}$ ranges from $90^{\circ}$ to $133^{\circ} \mathrm{W}$. $\mathrm{LDO}$ was deposited intermittently at the above sites from 15 to $4.4 \mathrm{Ma}$, but is concentrated at about $15,13-12,11,10-9.5,6.3-6.1$, and $4.4 \mathrm{Ma}$. A less widespread interval confined to Sites 847 and 849 occurred between 5.8 and $5.1 \mathrm{Ma}$. No laminated sediments occur after $4.4 \mathrm{Ma}$. A plot of LDO intervals on a plate motion backtracked chart (Fig. 3) shows that almost all were deposited when sites lay between $0^{\circ}$ and $2^{\circ} \mathrm{S}$, although mat fragments are present in deposits farther north (Sites 851, 852). An exception is Site 844 , which contains several early to middle Miocene age LDO intervals. The LDO and mat fragments (see Kemp, this volume) at Sites 844 and 845 may record the presence of a center of mat formation, separated from the equatorial region.

Within laminated episodes, individual beds may be correlated over great distances. For example, the distinctive $60-\mathrm{cm}$ bed of LDO that occurs at the base of the 4.4-Ma interval is present at Sites 847, 849, 850 , and 572 , and so may be correlated over a longitudinal extent of at least $2000 \mathrm{~km}$. As well as the close similarity of the sequences, correlation is based on biostratigraphy and continuous gamma-ray attenuation porosity evaluator (GRAPE) data (Mayer, Pisias, Janecek, et al., 1992; Mayer, 1991). The coincidence of the laminated intervals with abrupt changes in sediment density; hence, seismic impedance contrast should provide a means of correlating depositional events over great distances from seismic records (Mayer et al., 1985; Bloomer et al., this volume) in a critical area of the ocean basins.

\section{ECOLOGICAL SIGNIFICANCE OF Thalassiothrix}

Micropaleontological studies of the LDO indicate that Thalassiothrix longissima is the dominant species, although several different varieties or subspecies occur (see Pearce et al., this volume). The presence of Thalassiothrix in Neogene sediments from the eastern equatorial Pacific has been widely used as an indicator of significant upwelling and high primary production (Sancetta, 1982, 1983). Thalassiothrix longissima is characterized by long straight to twisted cells, between 1.5 and $5 \mu \mathrm{m}$ wide, but up to $4 \mathrm{~mm}$ long. Previous researchers have described it as a cosmopolitan species having a distribution that ranges from the Southern Ocean to the North Pacific, North Atlantic, and the Norwegian Sea (Hendey, 1937; Smayda, 1958; Hasle and Semina, 1987). However, this apparent wide-ranging distribution may result from differences in species definition and the assignment of other forms of Thalassiothrix sp. (e.g., T. antarctica, T. acuta, or 


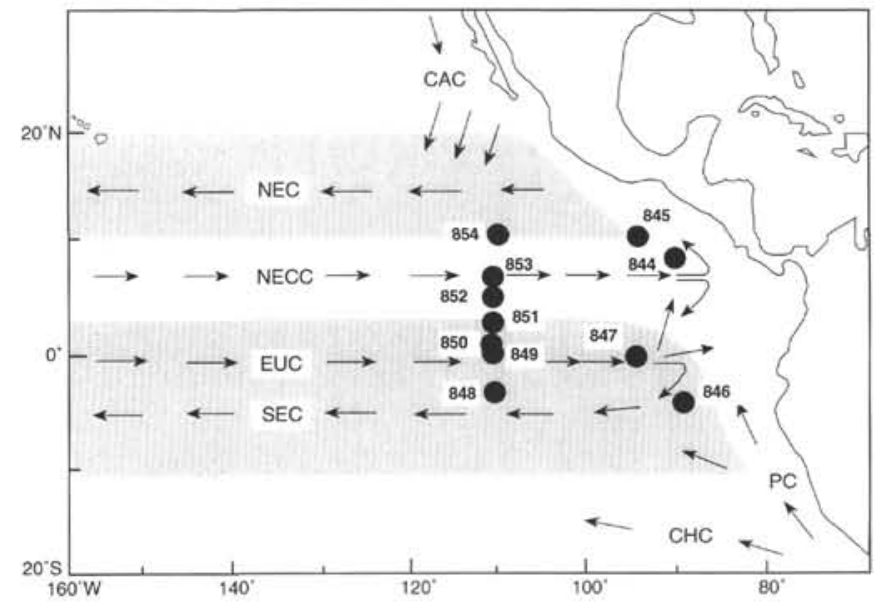

Figure 1. Location of Leg 138 sites showing the configuration of major equatorial current systems. $\mathrm{CAC}=$ California Current; $\mathrm{NEC}=$ North Equatorial Current; $\mathrm{NECC}=$ North Equatorial Countercurrent; $\mathrm{EUC}=$ Equatorial Undercurrent; $\mathrm{SEC}=$ South Equatorial Current; $\mathrm{CHC}=$ Chile Current; and $\mathrm{PC}=$ Peru Current.
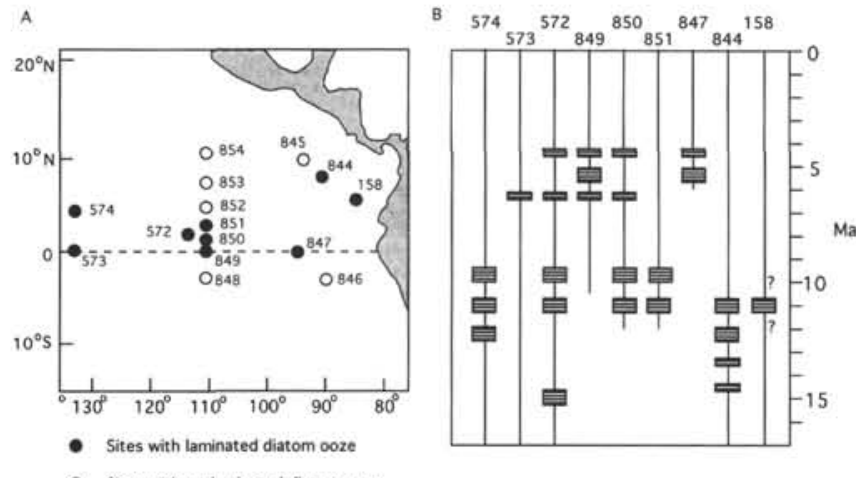

Figure 2. Geographical (A) and temporal (B) extent of episodes of laminated diatom mat deposition in the eastern equatorial Pacific.

T. heteromorpha) into T. longissima (Hasle and Semina, 1987). Species definitions notwithstanding, micropaleontological analysis of the LDOs recovered during Leg 138 indicates the presence of different varieties of $T$. longissima within individual bundles of laminae (see Pearce et al., this volume). Whether these represent different varieties, subspecies, or species must await more detailed taxonomic study of the Thalassiothrix Group and the LDO.

The few studies of $T$. longissima in the modern ocean have had a mainly taxonomic emphasis and contain little ecological information. T. longissima ranges in abundance up to $10^{3}$ to $10^{6}$ cells per liter and occurs as single cells, colonies, or is arranged in bundle-shaped colonies and large, tangled masses or mats (Hallegraeff, 1986; Hasle and Semina, 1987). The colonies or mats are formed, in part, by the attachment of several cells at the foot-pole, resulting in an arrangement resembling a "bunch of flowers." No data are available regarding the sinking or flotation characteristics of mats of $T$. longissima; however, several relevant recent studies of the mat-forming diatom Rhizosolenia have been used as an analog.

\section{Rhizosolenia: An Analogous Mat-forming Diatom}

No information is available about sinking characteristics of Thalassiothrix mats; however, new data from sediment trap studies have highlighted the significance of mass sinking of mats of rhizosolenid

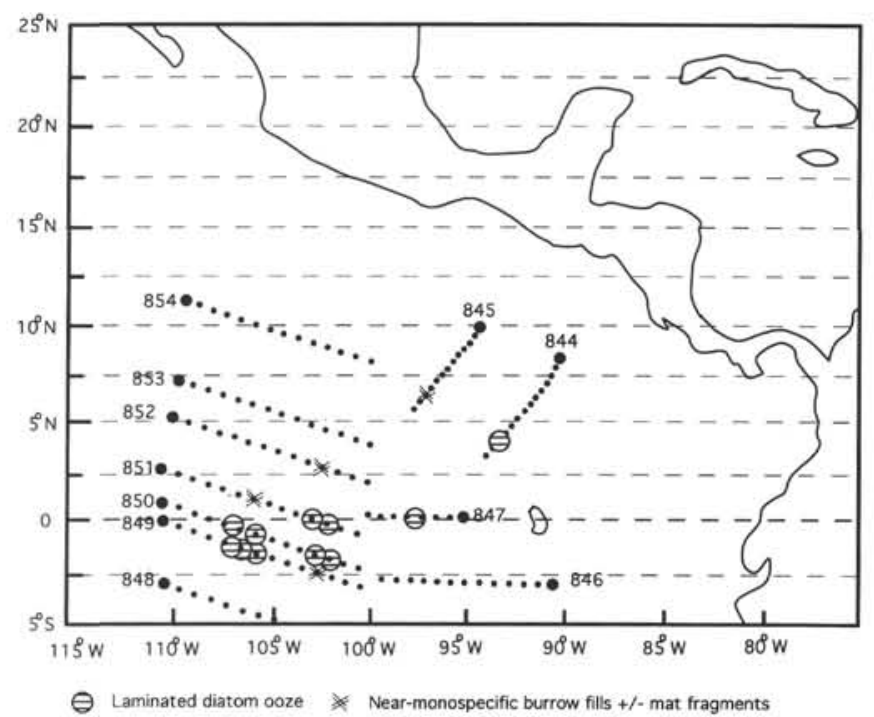

Figure 3. Plate-motion backtracked diagram showing location, through time, of laminated diatom mat deposits and traces of diatom mat deposition (burrow fills and mat fragments).

diatoms as agents of rapid flux to the seafloor (Sancetta et al., 1991). Concentrations of up to $4.4 / \mathrm{m}^{3}$ have previously been reported for Rhizosolenia mats (Martinez et al., 1983); however, massive concentrations of Rhizosolenia mats have been reported from the eastern equatorial Pacific during the Fall of 1992 (Barber, 1992; Barber et al., in press).

The 1992 Fall U.S. JGOFS experiment encountered a return to cold tongue (anti-El Niño or La Niña) conditions following the El Niño monitored during the spring cruises. Residual warm water north of $2^{\circ} \mathrm{N}$ led to the development of a sharp east-west front at $2^{\circ} \mathrm{N}$, monitored by aircraft, satellite, and the space shuttle, Atlantis, which extended for more than $1000 \mathrm{~km}$ (Barber, 1992; Barber et al., in press). This front separated colder water at $23.8^{\circ} \mathrm{C}$ to the south, which subducted to the north under the warmer water at $26.6^{\circ} \mathrm{C}$. Great patches and streamers of mats of the diatom Rhizosolenia occurred on the north (warm) side of the front. Apparently, the mats (though not a major component of the plankton in the cold, highly productive waters south of the front) were so buoyant as to "pop up" to form an almost contiguous layer a few centimeters from the surface on the warm side of the front. These layers of mats, which locally extended several kilometers away from the front, caused localized, near-surface, water column stratification; starved of nutrients and overheated, the mats appear to have subsequently died and sunk (Barber, pers. comm., 1992) (Fig. 4). Thus, the physics of the frontal system facilitates the concentration of the diatom mats, which might not otherwise be a significant component of either the phytoplankton or of "new" or "export" production.

\section{A Depositional Model for the $T$. longissima Mat Deposits}

Individual, submillimeter laminae in all the laminated diatom ooze intervals in the eastern equatorial Pacific contain stacks of typically 20 to 30 individual $20-\mu \mathrm{m}$-thick mats, but occasionally these contain up to 200 mats. These $T$. longissima laminae are interlayered with very thin laminae that contain mixed microfossil assemblages (Pearce et al., this volume) that represent "normal" equatorial sediments. The $T$. longissima laminae probably represent the fallout from individual mat-forming/mat-flux episodes, when large numbers of mats were concentrated and sank en masse (Fig. 5). By analogy with the Rhizosolenia mat-forming events monitored by JGOFS, these episodes of mat flux may record La Niña (anti-El Niño) events when strong east-west frontal zones developed. The millimeter-to-centimeter scale alterna- 


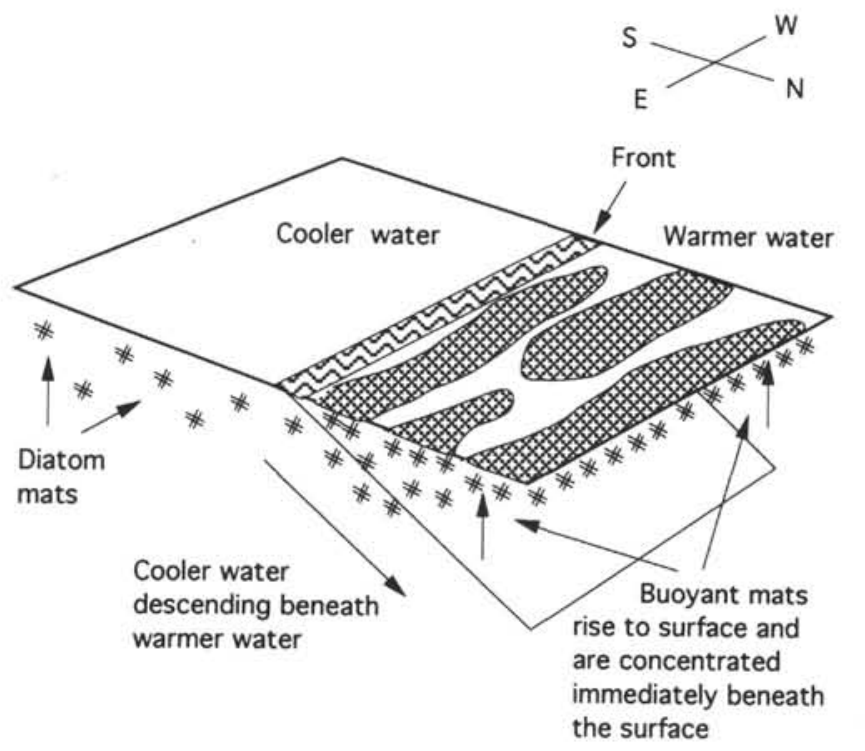

Figure 4. Synoptic diagram showing the concentration of diatom mats at an oceanic frontal zone. The self regulation of diatom mat buoyancy is disturbed as the colder water sinks beneath the warmer water. The mats rise to form a concentrated surface layer on the warm side of the front. These mats will subsequently die through nutrient exhaustion and overheating and sink. Thus, diatoms, which need not represent a large portion of the primary production on the cold side of the front, may represent a large part of the export production beneath the frontal zone. (The model is based on processes at the "great front" encountered by the 1992 Fall JGOFS cruises reported in Barber [1992] and Barber et al. [in press].)

tions in the laminated diatom ooze, which record periods of more or less intense mat flux, represent time scales of several years to several tens of years and may record periods of stronger/weaker, El Niño/La Niña cycles. The origin of the decimeter-scale interbedding between LDO and nannofossil ooze (representing time scales from hundreds to a few thousand years) may relate to variations in intensity of circulation, with more vigorous surface circulation leading to the development of stronger frontal systems and, consequently, greater mat flux. Alternatively, these might relate to fluctuations in nutrient supply. Any explanation for these must provide a mechanism for the abrupt onset of mat deposition.

The presence of near-monospecific burrow fills and mat fragments outside the narrow $2^{\circ}$ latitudinal limit of LDO suggests considerable dispersal of smaller quantities of diatom mats (Fig. 3).

\section{PRESERVATION OF LAMINATION IN THE T. longissima MAT DEPOSITS: IMPLICATIONS FOR INTERPRETATION OF LAMINATED SEDIMENT SEQUENCES}

The preservation of lamination in marine sediments (which forms a record of sequential flux events) has been universally regarded as resulting from the reduction or elimination of benthic animal activity by reduced bottom water oxygenation. Marine environments that are perceived to promote lamina preservation include the bottoms of anoxic silled basins, such as the Black Sea (Hay, 1988) or California borderland basins (Gorsline, 1984); zones of strong coastal upwelling, where an oxygen minimum layer intersects the shelf or slope, such as off Peru (Kemp, 1990) or within the Gulf of California (Calvert, 1966). In the light of these models, the presence of widespread laminated sediments on the deep seafloor of the eastern equatorial Pacific comes as a great surprise, as this region is not one associated with reduced oxygen levels (Kamykowski and Zentara, 1990). Studies of benthic foraminifers (sensitive indicators of oxygenation) through

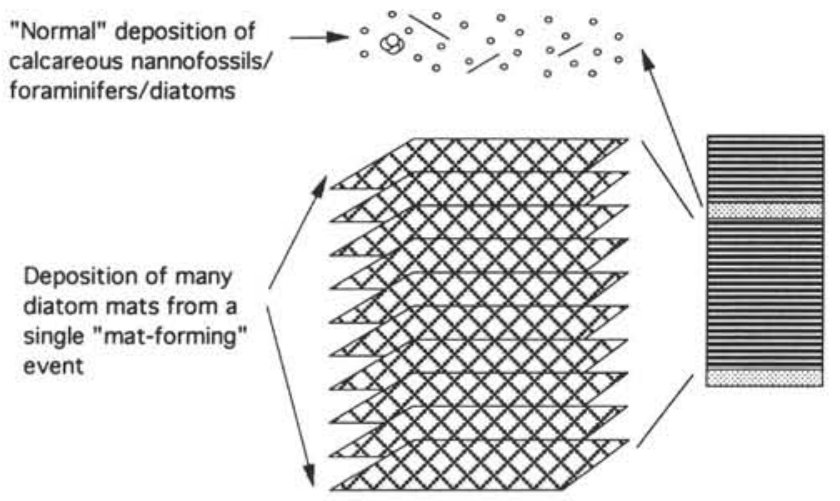

Figure 5. Depositional model for the laminated mat deposits of the eastern equatorial Pacific. Stacks of generally around 25, but exceptionally, up to 200 mats, have been deposited from a single mat-forming event to produce a $T$. longissima lamina. These have been interlaminated with thinner laminae that contain mixed microfossil assemblages, representing more normal equatorial deposition.

these laminated intervals show no evidence for any increase in species characteristic of a low oxygen environment, but rather, a decrease in tapered cylindrical and infaunal forms, attesting to the impenetrability of the diatom mat meshwork (King et al., this volume).

\section{Independent Evidence for Strength of the Diatom Mat Meshwork}

Such is the tensile strength of individual laminations that some are seen to have been partially pulled out of the core during piston-coring or by the wire during core-splitting. Wire core-splitting caused considerable deformation of laminated intervals, making recognition of laminations difficult, but producing a characteristic roughened surface. Only in the deeper intervals was a saw used for core-splitting, very nearly destroying the core, but revealing obvious laminations on cut surfaces. During coring operations, the first penetration of even a thin bed of laminated sediment coincided with an abrupt increase in extraction overpull for the piston corer from typical values of 20,000 to $40,000 \mathrm{lb}$ to values of up to $150,000 \mathrm{lb}$.

Thus, the diatom meshwork in the $T$. longissima laminae was of sufficient tensile strength and impenetrability to suppress benthic activity. During individual mat-flux events, with sedimentation, probably in days, of single layers up to 400 mats thick, the benthos was overwhelmed, resulting in complete preservation of the mats, which can be essentially regarded as prefabricated laminae. Laminae, therefore, were preserved by physical means, rather than by reduced availability of dissolved oxygen. An important implication of this method of preservation is that deposition of small quantities of mats that did not overwhelm the benthos would not be preserved as laminae. Such intervals, containing abundant specimens of $T$. longissima, occur intermittently throughout the sequence, but are present in typical bioturbated pelagic sediments.

\section{Implications for Other Deep-Sea, Near-monospecific and/or Laminated Giant Diatom Oozes}

The physical suppression of bioturbation by diatom mats as a mechanism for preservation of lamination in the T. longissima oozes of the eastern equatorial Pacific Ocean has major implications for the origins of other enigmatic, near-monospecific and commonly laminated deep-sea diatom oozes of Neogene and Quaternary age (Gardner and Burckle, 1975; Gombos, 1984; Muller et al., 1991). Because of the laminated nature of these deposits, and given the existing preconceptions, origins have previously been ascribed to reduced oxygen conditions. For example, Muller et al. (1991) suggested that the presence 


\section{GRAPE}

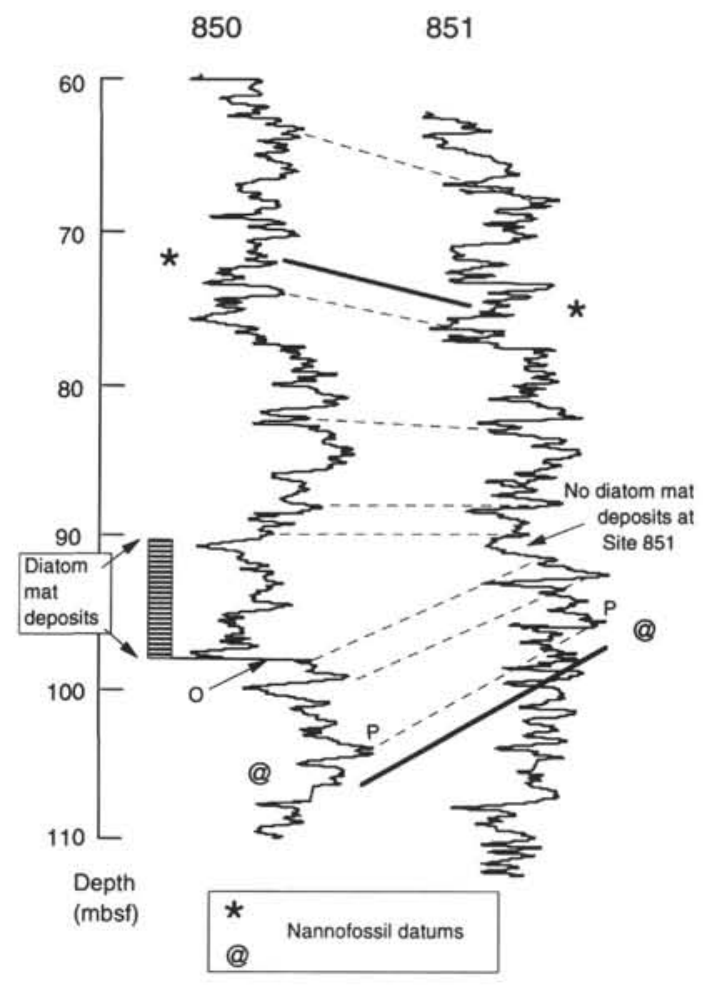

Figure 6. Correlation of the GRAPE records of Sites 850 and 851 through the 4.4-Ma mat deposition episode. Although the rest of the GRAPE signal correlates excellently, no record is seen of the $\sim 8$-m-thick diatom mat deposits of the 4.4-Ma interval at Site 851 . Note that mat deposition is preceded by a carbonate maximum $(\mathrm{P}) .(\mathrm{O})=$ onset of intense diatom mat deposition at Site 850.

of laminated oozes of the giant diatom Bruniopsis mirabilis in Messinian sediments from the South Atlantic relate to periods of (implausible) deep-sea, reduced bottom-water oxygenation. Gombos (1984) ascribed a similar origin to laminated oozes of the giant diatom Ethmodiscus rex at DSDP Site 520. Interestingly, E. rex is a diatom that, like the Rhizosolenia mats, is also capable of positive buoyancy. Furthermore, dead Ethmodiscus cells sink at speeds of up to $510 \mathrm{~m} /$ day (Villareal, 1992). Whether the E. rex sank as aggregates or as single cells, the mass sinking of this giant diatom may have led to the preservation of lamination by physical suppression of benthos, and obviates the need to appeal to an unlikely and ad hoc period of reduced bottom-water oxygenation. Interestingly, many of the Atlantic Quaternary E. rex ooze deposits are in sites beneath or near localized, recurring frontal zones, and the timing of some of the major, late Quaternary equatorial Atlantic E. rex oozes, coincide with glacial build-up (Stabell, 1986) when more intense frontal system development would be driven by increased wind strength.

Intriguingly, the timing of the E. rex ooze deposition at Site 520 and the $B$. mirabilis deposition at Site 701 appear to be coeval with the most intense period of mat deposition in the eastern equatorial Pacific: the 6.3- to 6.1-Ma event. This might suggest that general physical oceanic conditions favored mat production/flux at this time, perhaps implying high pole-to-equator gradients and enhanced formation of stronger oceanic frontal systems.

\section{IMPLICATIONS FOR CARBONATE/SILICA VARIATION IN SEDIMENTS}

The $T$. longissima mat deposits, which are the direct result of surface processes, are clear evidence that surface processes, not disso- lution at depth, controlled many of the major changes in the relative abundance of carbonate and silica during the Neogene, at least in the equatorial Pacific. After extensive scanning electron microscope (SEM) studies of the laminated mat deposits, we found no evidence that carbonate dissolution has occurred preferentially in the monospecific $T$. longissima diatom meshwork (Pearce et al., this volume). Individual, well-preserved coccoliths (calcareous nannoplankton) occur occasionally, but persistently, through most of the mat deposits examined thus far. Planktonic and benthic foraminifers may show some effects of dissolution, but no more in the T. longissima laminations than in the carbonate-rich laminations. A synthesis of regional sedimentology shows that the episodes of diatom mat deposition do not coincide with major episodes of carbonate dissolution (Kemp, this volume).

The episodic mass sinking of diatoms distorts the normal carbonate-silica cyclicity observed. Because the mats have been deposited much more rapidly than the surrounding nannofossil ooze, the usual assumptions of uniform sedimentation rates between age "picks," upon which most paleoceanographic techniques rely, are invalid. Indeed, the signal from the mat-flux episodes may have to be filtered or "squeezed" out to permit conventional Milankovitch band analysis or production of "tuned" GRAPE-based time scales (see Shackleton et al., this volume).

The GRAPE record (giving carbonate-opal variation, Mayer, 1991) generally shows excellent correlation between equatorial sites (Lyle et al., 1992). However, when comparing intervals where one site has significant LDO and another has none, this correlation breaks down. For example, at two closely spaced sites (Sites 850 and 851; Fig. 6), the 4.4-Ma mat deposits are present at Site 850, but not at Site 851 . Although the rest of the GRAPE signal correlates excellently, no record of the approximately 8-m-thick diatom mat deposits can be seen at Site 851. This major difference in the sedimentary record of the two sites highlights the geographically restricted distribution of the laminated diatom ooze.

\section{DISCUSSION}

Inspection of the GRAPE signals, (e.g., in Fig. 6), also reveals another intriguing aspect of these episodes of mat deposition. The peaks (indicated by "P") represent the purest carbonate sediments having a minimum opal content. Each major interval of laminated diatom mat deposits is underlain by such a carbonate maximum. These carbonate maxima do not immediately precede the abrupt onset of mat deposition ( $\mathrm{O}$ in Fig. 6), but appear to be consistently followed by the same distinctive pattern of decrease, then increase, then abrupt decrease in carbonate content. Together, these major cycles represent the most abrupt and largest magnitude changes in carbonate-silica cyclicity in the equatorial Pacific. These major cycles currently are being investigated using a range of interdisciplinary sedimentologi$\mathrm{cal}$, micropaleontological, and isotopic techniques.

The intervals of mat deposition between 14.6 and $9.5 \mathrm{Ma}$ occurred during a period of many major episodes of ocean cooling and reorganization, including a shift in the main locus of silica deposition from the Atlantic to the Pacific Ocean (Baldauf and Barron, 1990; Barron and Baldauf, 1990). The 6.3 to 6.1 Ma interval represents the most rapid burst of mat deposition and opal export in the eastern equatorial Pacific. The timing of this (during the early Messinian) and the apparently synchronous deposition of LDO at high sedimentation rates in the South Atlantic (see above) raise questions about major variations in the silica cycle and the relation of these to major oceanographic events. Attempts to quantify opal fluxes during this period currently are underway.

The cessation of laminated sediment deposition after 4.37 Ma coincides with a shift in silica production from the equatorial Pacific to the Antarctic circum-polar ocean (Leinen, 1979; Brewster, 1980) with the continued growth of the ice sheets and approximates the closure of the Pan-American Seaway (Keigwin, 1982). At present, one can only speculate as to the cause of this cessation. Possible mechanisms range 
from a change in nutrient supply relating to differences in communication between the Atlantic and Pacific oceans, to changes in circulation, or to a combination of the effects of these on diatom ecology.

\section{CONCLUSIONS}

From the combined evidence of the Leg 138 results and the Fall JGOFS cruise, the best model for the generation of deep-sea diatom mat deposits (manifest as near-monospecific LDO) is one of generation at sharp oceanic frontal zones. Such frontal zones provide mechanisms both for concentrating buoyant diatom aggregates or mats and then killing and sinking them. The evidence of the Thalassiothrix mat deposits suggests that such frontal systems may have generated flux at rates one or two orders of magnitude faster than "normal" high equatorial sedimentation rates. The mat deposits appear to be a key part of major carbonate-silica variations in the equatorial Pacific, whose significance and origins demand further study.

\section{ACKNOWLEDGMENTS}

The contributions of Pearce and Kemp were supported by a NERC ODP Special Topic research grant and the Maurice Hill fund of the Royal Society (Kemp). Baldauf acknowledges support from USSAC. We are grateful to Dick Barber, Connie Sancetta, and many of our Leg 138 colleagues for stimulating discussions.

\section{REFERENCES*}

Baldauf, J.G., and Barron, J.A., 1990. The distribution of Eocene through Quaternary biosiliceous sediments: a distribution resulting in part from Polar cooling. In Bliel, U., and Thiede, J. (Eds.), Geological History of the Polar Oceans: Arctic versus Antarctic: Dordrecht (Kluwer), 575-607.

Barber, R.T., 1992. Fall survey cruise finds cooling conditions in equatorial Pacific. U.S. JGOFS News, 4:1-6.

Barber, R.T., Murray, J.W., Jr., McCarthy, J.J., in press. Biogeochemical interactions in the equatorial Pacific. Ambio.

Barron, J.A., and Baldauf, J.G., 1990. Development of biosiliceous sedimentation in the North Pacific during the Miocene and Early Pliocene. In Tsuchi, R. (Ed.), Pacific Neogene Events: Their Timing, Nature and Interrelationship: Tokyo (Univ. of Tokyo Press), 43-63.

Berggren, W.A., Kent, D.V., Flynn, J.J., and Van Couvering, J.A., 1985. Cenozoic geochronology. Geol. Soc. Am. Bull., 96:1407-1418.

Brewster, N.A., 1980. Cenozoic biogenic silica sedimentation in the Antarctic Ocean, based on two Deep Sea Drilling Project Sites. Geol. Soc. Am. Bull., 91:337-349.

Calvert, S.E., 1966. Origin of diatom-rich varved sediments from the Gulf of California. J. Geol., 74:546-565.

Chavez, F.P., and Barber, R.T., 1987. An estimate of new production in the equatorial Pacific. Deep-Sea Res. Part A, 34:1229-1243.

Chavez, F.P., Buck, K.R., and Barber, R.T., 1990. Phytoplankton taxa in relation to primary production in the equatorial pacific.Deep-Sea Res. Part A, 37:1733-1752.

Gardner, J.V., and Burckle, L.H., 1975. Upper Pleistocene Ethmodiscus rex oozes from the eastern equatorial Atlantic. Micropaleontology, 21:236-242.

Gombos, A.M., Jr., 1984. Late Neogene diatoms and diatom oozes in the central South Atlantic. In Hsü, K.J., LaBrecque, J.L., et al., Init. Repts. DSDP, 73: Washington (U.S. Govt. Printing Office), 487-494.

Gorsline, D., 1984. Studies of fine grained sediment transport processes and products in the California continental Borderland. Geol. Soc. Spec. Publ. London, 15:395-415.

Hallegraeff, G.M., 1986. Taxonomy and morphology of the marine planktonic diatoms Thalassionema and Thalassiothrix. Diatom Res., 1:57-80.

Hasle, G.R., and Semina, H.J., 1987. The marine planktonic diatoms Thalassiothrix longissima and Thalassiothrix antarctica with comments on Thalassionema spp. and Synedra Reinboldii. Diatom Res., 2:175-192.

Hay, B.J., 1988. Sediment accumulation in the Central Western Black Sea over the past 5100 years. Paleoceanography, 30:491-508.

Hendey, N.I., 1937. The plankton diatoms of the southern seas. Disc. Rep., 16:151-364.

Kamykowski, D., and Zentara, S.-J., 1990. Hypoxia in the world ocean as recorded in the historical data set. Deep-Sea Res. Part A, 37:1861-1874.
Keigwin, L.D., 1982. Isotopic Paleoceanography of the Caribbean and East Pacific: role of Panama uplift in late Neogene time. Science, 217:350-353.

Kemp, A.E.S., 1990. Sedimentary fabrics and variation in lamination style in Peru continental margin upwelling sediments. In Suess, E., von Huene, R., et al., Proc. ODP, Sci. Results, 112: College Station, TX (Ocean Drilling Program), 43-58.

Kemp, A.E.S., and Baldauf, J.G., 1993. Vast Neogene laminated diatom mat deposits from the eastern equatorial Pacific Ocean. Nature, 362:141-144.

Leinen, M., 1979. Biogenic silica accumulation in the central equatorial Pacific and its implications for Cenozoic paleoceanography. Geol. Soc. Am. Bull., 90:801-803.

Lyle, M., Mayer, L., Pisias, N., Hagelberg, T., Dadey, K., Bloomer, S., and the Shipboard Scientific Party of Leg 138, 1992. Downhole logging as a paleoceanographic tool on Ocean Drilling Program Leg 138: interface between high-resolution stratigraphy and regional syntheses. Paleoceanography, 7:691-700.

Martinez, L., Silver, M.W., King, J., and Alldredge, A.L., 1983. Nitrogen fixation by floating diatom mats: a source of new nitrogen to oligotrophic ocean waters. Science, 221:152-154.

Mayer, L., Pisias, N., Janecek, T., et al., 1992. Proc. ODP, Init. Repts., 138 (Pts. 1 and 2): College Station, TX (Ocean Drilling Program).

Mayer, L., Theyer, F., Thomas, E., et al., 1985. Init. Repts. DSDP, 85: Washington (U.S. Govt. Printing Office).

Mayer, L.A., 1991. Extraction of high-resolution carbonate data for paleoclimate reconstruction. Nature, 352:148-150.

Mayer, L.A., Shipley, T.H., Theyer, F., Wilkens, R.H., and Winterer, E.L., 1985. Seismic modeling and paleoceanography at Deep Sea Drilling Project Site 574. In Mayer, L.A., Theyer, F., Thomas, E., et al., Init. Repts. DSDP, 85: Washington, (U.S. Govt. Printing Office), 947-970.

Mayer, L.A., Shipley, T.H., and Winterer, E.L., 1986. Equatorial Pacific seismic reflectors as indicators of global oceanographic events. Science, 233:761-764.

Müller, D.W., Hodell, D.A., and Ciesielski, P.F., 1991. Late Miocene to earliest Pliocene (9.8-4.5 Ma) Paleoceanography of the subantarctic Southeast Atlantic: stable isotopic, sedimentologic, and microfossil evidence. In Ciesielski, P.F., Kristoffersen, Y., et al., Proc. ODP, Sci. Results, 114: College Station, TX (Ocean Drilling Program), 459-474.

Sancetta, C., 1982. Diatom biostratigraphy and paleoceanography, Deep Sea Drilling Project Leg 68. In Prell, W.L., Gardner, J.V., et al., Init. Repts. DSDP, 68: Washington (U.S. Govt. Printing Office), 301-309.

1983. Biostratigraphic and paleoceanographic events in the eastern equatorial Pacific: results of Deep Sea Drilling Project Leg 69. In Cann, J.R., Langseth, M.G., Honnorez, J., Von Herzen, R.P., White, S.M., et al., Init. Repts. DSDP, 69: Washington (U.S. Govt. Printing Office), 311-320.

Sancetta, C., Villareal, T., and Falkowski, P., 1991. Massive fluxes of rhizosolenid diatoms: a common occurrence? Limnol. Oceanogr., 36:1452-1457.

Smayda, T.J., 1958. Biogeographical studies of marine phytoplankton. Oikos, 9:158-191.

Smith, K.L., Baldwin, R.J., and Williams, P.M., 1992. Reconciling particulate organic carbon flux and sediment community oxygen consumption in the deep North Pacific. Nature, 359:313-316.

Stabell, B., 1986. Variations of diatom flux in the eastern equatorial Atlantic during the last 400,000 years ("Meteor" cores 13519 and 13521). Mar. Geol., 72:305-323.

van Andel, T.H., Heath, G.R., and Moore, T.C., Jr., 1975. Cenozoic history and paleoceanography of the central equatorial Pacific Ocean. Mem.-Geol. Soc. Am. 143.

Villareal, T.A., 1992. Buoyancy properties of the giant diatom Ethmodiscus. J. Plankt. Res., 14:459-463.

Villareal, T.A., Altabet, M.A., and Culver-Rymsza, K., 1993. Nitrogen transport by vertically migrating diatom mats in the North Pacific Ocean. Nature, 363:709-712.

Wyrtki, K., 1981. An estimate of equatorial upwelling in the Pacific. J. Phys. Oceanogr., 11:1205-1214.

Abbreviations for names of organizations and publication titles in ODP reference lists
follow the style given in Chemical Abstracts Service Source Index (published by American Chemical Society).

Date of initial receipt: 13 July 1993

Date of acceptance: 8 March 1994

Ms 138SR-134 